GENETICS

AND PROBABILITY

IN ANIMAL BREEDING

EXPERIMENTS 


\section{GENETICS \\ AND PROBABILITY \\ IN ANIMAL BREEDING \\ EXPERIMENTS}

A primer and reference book on probability, segregation, assortment, linkage and mating systems for biomedical scientists who breed and use genetically defined laboratory animals for research

\section{EARL L. GREEN}


() Earl L. Green 1981

Softcover reprint of the hardcover 1st edition 1981

All rights reserved. No part of this publication may be reproduced or transmitted, in any form or by any means, without permission

First published 1981 by

The Scientific and Medical Division

MACMILLAN PUBLISHERS LTD

London and Basingstoke

Associated companies in Delhi Dublin

Hong Kong Johannesburg Lagos Melbourne

New York Singapore and Tokyo

Typeset by

Reproduction Drawings Ltd, Sutton, Surrey

ISBN 978-1-349-04906-6 ISBN 978-1-349-04904-2 (eBook)

DOI $10.1007 / 978-1-349-04904-2$

This book is sold subject to the standard conditions of the Net Book Agreement 
Dedicated to

THE JACKSON LABORATORY,

founded in 1929;

to its founder,

a man of vision;

and to its people,

past, present, and future;

on the occasion of its fiftieth anniversary in 1979 


\section{Preface}

For nearly 20 years, I was Director of the Jackson Laboratory in Bar Harbor, Maine, one of the world's centres for research in mammalian genetics. During most of those years, I gave a series of lectures on genetics and mouse breeding to each year's new crop of staff members and postdoctoral fellows. This book is an expanded version of those lectures. It is intended to be useful to research workers who are just starting to work with genetically defined animals, such as mice of various inbred strains, and who need an introduction to the probability aspects of transmission genetics in order to enrich their understanding of the kinds of animals already available and to guide them in the design and analysis of their own breeding experiments.

The new staff members and postdoctoral fellows I dealt with had many different formal educational backgrounds. They included physiologists, biochemists, embryologists, psychologists, pathologists, immunologists, microbiologists and physical chemists. The yearly group also included geneticists, but contemporary geneticists are of many kinds: cytogeneticists, behavioural geneticists, biochemical geneticists, physiological geneticists, immunogeneticists, developmental geneticists, radiation geneticists and quantitative geneticists. All of these kinds of scientists usually have a working knowledge of the classical principles of heredity and of the classical methods of statistical inference. Yet, except for the quantitative geneticists, they usually feel uneasy with the probability aspects of transmission genetics and with the methods of statistical inference for discrete variables.

Scientists of this sort will soon encounter the folkways and jargon of the geneticists who breed laboratory animals. They will want to know, and will need to know: how new genes are discovered, how one establishes that a new gene is not like any already known gene, how one finds the position of a new genetic locus on the chromosome map, how alike are the animals of an inbred strain, how many generations of breeding does one have to arrange to ensure a given probability of alikeness, how many matings should one make up and how many progeny per mating should one observe in each generation when perpetuating a recessive mutation? Answers to questions of this sort will be found in the following pages.

This book is intended, in two ways, to meet the needs of research workers who use laboratory animals: first, as a coherent self-contained account of the probability 
and statistical aspects of laboratory animal breeding and, second, as a ready reference book for terminology and formulae. The organisation of the book reflects these two objectives. To provide an account, the reader is conducted through five model breeding experiments of the sort that he, himself, may soon want to carry out in his own research. To provide a ready reference, the more useful formulae are assembled in tables or, otherwise, are identified by serial numbers within chapters.

I am assuming that everyone who reads this book knows that the units of heredity are called genes and that genes are located on chromosomes. I am also assuming that everyone knows about the elementary principles of transmission genetics: segregation of alleles and assortment or recombination of non-alleles; and that the genetic phenomena of segregation and assortment exactly parallel the chromosomal phenomena of disjunction, assortment and crossing-over during germcell formation. The book deals with various modifications and complexities of these elementary principles of transmission genetics. It does not deal with the molecular nature of the gene, nor with how genes replicate or how they make proteins, for these aspects of physical, physiological, developmental and biochemical genetics are not relevant to its purpose.

I am further assuming that the reader's background in the probabtlity aspects of genetics is skimpy at best, even though he or she is familiar with the $1: 1$ and $1: 1: 1: 1$ segregation ratios of backcrosses and the $3: 1$ and $9: 3: 3: 1$ segregation ratios of intercrosses for one and two loci. Such readers should find many familiar concepts of a first course in genetics recast in a more sophisticated symbolism of probability and thereby put into forms that lead to symbolic predictions and bases for statistical inferences about the outcomes of breeding procedures. Even so, the reader's level of mathematical competence need not exceed algebra. All manipulations requiring calculus have been relegated to appendices.

The book is intended to be read, to be studied and to be used as a reference. Yet it is not cast in the form of a textbook. I have tried to compensate for this deliberate omission by including numerous worked examples in the text. Beyond that I suggest that for such exercises the interested reader should procure elementary textbooks on probability and statistics and on experimental genetics, of which there are dozens of good ones now available.

As a convenience in exposition and as a reflection of my own first-hand familiarity, I have referred to mice throughout the text. Yet the concepts and methods described in the book are applicable to any bisexual organism whose reproductive pattern is similar to that of mice. This includes all the common laboratory mammals: rats, guinea pigs, hamsters, rabbits, gerbils, nutria, cats and dogs.

This book deals with the overlap of the domain of genetics and the domain of probability. To pursue that figure of speech just a bit further: each domain has some lofty peaks and some profound caverns. To ascend the peaks or to explore the caverns would require special hand tools and foot gear. Our explorations will, instead, be confined to the gentle paths among the foothills between the domains, with short excursions into a few nooks and crannies. Soft-soled shoes and hand-held calculators are all we shall need.

The first chapter is composed of extremely condensed statements about the 
concepts of probability needed for genetic predictions and the methods of statistics needed in the analysis of genetic data. My emphasis is on the meaning and use of the numerous concepts and methods needed by the laboratory animal breeder. Biologists who feel repelled by statistical notation may prefer to skim this chapter at first reading and refer to it only when a particular idea in a later chapter depends upon a formula in chapter 1 .

Chapters 2 and 3 are devoted to deriving Mendel's principles of heredity from the data of a few mouse breeding experiments, but with emphasis on full probabbility statements of these principles rather than upon the ratios of more elementary treatments.

Chapter 4 , on linkage, is like chapters 2 and 3, on segregation and assortment, in putting the concepts in probability form. Chapter 5 does the same thing for various regular systems of mating in widespread use, but also uses the probability results to predict the genetic consequences of using the systems over many generations.

The appendices are essential for the serious breeder of laboratory animals, both for extensions of the theoretical aspects and the practical problems he will face. Appendices 1-7 contain technical details that I thought should be removed from the text because they require more mathematical preparation than I am assuming for most of the users of this book. They are, however, an invitation to the reader to delve a little deeper into the fascinating topics of linkage estimation and of analysis of mating systems. Appendix 7 deals with the practical problems of how many animals to raise and how many matings to make up for various mating systems described in chapter 5 . Appendices 8,9 and 10 deal with the intensely practical problems of nomenclature of genes and strains of mice, of a record-keeping system for breeding laboratory animals, and of mouseroom layout and operation.

The elaboration of the principles of transmission genetics is largely the work of Sewall Wright, R. A. Fisher and J. B. S. Haldane, along with those who followed in their wake. I have not given references to the origin of each probability and statistical statement in this elementary introduction. The formulae, or the fundamental relationships from which they are derived, can be found in the vast writings on genetics, probability and statistics in the middle two quarters of this century. I have, however, given references to various contemporary sources of general information about genetics, probability and statistics and to specific recent developments cited in the text.

I am indebted to several people for direct encouragement with respect to the preparation of this book. My thanks are especially due to my wife, Margaret C. Green, and to my former colleagues at the Jackson Laboratory, Donald W. Bailey and Robert L. Collins, for reading the text critically during its preparation. My thanks are also due to Randall $\mathrm{C}$. Adams for carrying out the computations used for the figures in chapter 5 . 


\section{Contents}

Preface

Chapter 1 Probability and statistics 1

$\begin{array}{lll}1.1 & \text { Variables and probabilities } & 2\end{array}$

1.2 Empirical probabilities 3

1.3 Theoretical probabilities 4

1.4 Points, probabilities and events 4

1.5 Complements and unions $\quad 5$

1.6 Union of mutually exclusive events $\quad 6$

1.7 Union of intersecting events $\quad 8$

1.8 Conditional probabilities 9

1.9 Terminology 12

$\begin{array}{lll}1.10 & \text { Summary about probability } & 12\end{array}$

1.11 Binomial distribution 13

1.12 Products of binomial distributions 17

1.13 Multinomial distributions 18

1.14 Mean and variance of binomial and multinomial distributions 19

1.15 Areas of the normal distribution 21

1.16 Maximum likelihood estimates of parameters 23

\begin{tabular}{ll}
1.17 & Amount of information \\
\hline
\end{tabular}

1.18 Terminology 24

1.19 Estimating an unknown probability 25

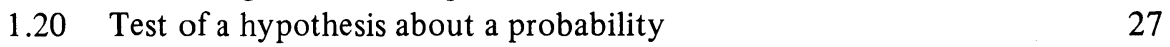

1.21 Errors in testing statistical hypotheses 29

1.22 Test of a difference between two proportions 30

1.23 Comparing class frequencies $\quad 32$

1.24 Partitioning deviations 36

$\begin{array}{lll}1.25 & \text { Orthogonal functions } & 37\end{array}$

1.26 Matrix algebra 39

1.27 Sources $\quad 39$ 
Chapter 2 Segregation of alleles $\quad 41$

2.1 Experiment 1: Matings of pale eared and normal eared mice 42

$\begin{array}{ll}\text { Proportions and probabilities } & 44\end{array}$

Inferences, symbols and assumptions $\quad 45$

$\begin{array}{lll}2.2 & \text { Definitions } & 47\end{array}$

2.3 Modified and disturbed segregations $\quad 50$

2.4 Estimation of the differential viability parameter $\quad 54$

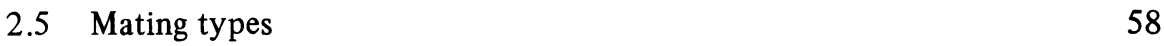

2.6 Nomenclature $\quad 59$

$\begin{array}{llr}2.7 & \text { Sources } & 59\end{array}$

Chapter 3 Assortment of non-alleles $\quad 61$

3.1 Experiment 2: Matings of mice with pale ears and dilute coats 61

$\begin{array}{ll}\text { Symbols } & 65\end{array}$

Gametic output $\quad 66$

$\begin{array}{ll}\text { Mating types } & 67\end{array}$

$\begin{array}{ll}\text { Inference } & 70\end{array}$

3.2 Other two-locus phenotypic ratios $\quad 70$

$\begin{array}{ll}\text { Codominance } & 71\end{array}$

$\begin{array}{ll}\text { Epistasis } & 72\end{array}$

3.3 Experiment 3: Matings of albino and himalayan mice 73

$\begin{array}{ll}\text { Inferences } & 75\end{array}$

3.4 Concept of the gene 75

$\begin{array}{lll}3.5 & \text { Sources } & 76\end{array}$

Chapter 4 Linkage, recombination and mapping $\quad 77$

4.1 Experiment 4: Matings of mice with pale ears and ruby eyes 77

$\begin{array}{ll}\text { Definitions and symbols } & 80\end{array}$

4.2 Gametic output $\quad 81$

$\begin{array}{ll}4.3 & \text { Kinds of mice and mating types }\end{array}$

4.4 Kinds of progeny and their probabilities 86

4.5 Maximum likelihood estimates of the linkage parameter 91

4.6 Extensions and complications 98

4.7 Use of a recombination fraction as a map distance 99

4.8 Summary on segregation, assortment and linkage 101

4.9 Experiment 5: A three-point cross involving extra toes, 101 muted and pearl

$\begin{array}{lll}4.10 & \text { Mapping functions } & 106\end{array}$

4.11 Linkage map of the mouse 108

$\begin{array}{ll}4.12 & \text { Linkage testing stocks } \\ 4.13 & \text { Sources }\end{array}$

$\begin{array}{lll}4.13 \text { Sources } & 112\end{array}$ 
$\begin{array}{lll}\text { Chapter } 5 & \text { Mating systems } & 114\end{array}$

$\begin{array}{lll}5.1 & \text { Experimental designs } & 115\end{array}$

Comparison of treatments $\quad 115$

Correlation between variables $\quad 116$

Effects of mutated genes $\quad 116$

$\begin{array}{ll}\text { Discovery of new genetic traits } & 117\end{array}$

Genetic dissection of complex traits $\quad 117$

Use of random-bred mice $\quad 117$

$\begin{array}{ll}5.2 \quad \text { Kinds of mice } & 117\end{array}$

$\begin{array}{ll}5.3 & \text { Symbols and definitions } \\ 5.4 & 118\end{array}$

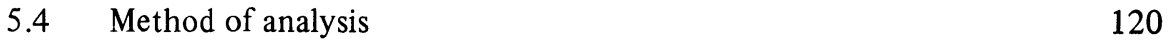

$\begin{array}{lll}5.5 & \text { Inbred strains } & 124\end{array}$

Brother-sister inbreeding (system 1) 126 Illustration 129

Ratios of successive probabilities $\quad 131$

Nomenclature 131

$\mathrm{F}_{1}$ hybrids 131

$\begin{array}{lll}5.6 & \text { Recombinant inbred strains } & 133\end{array}$

$\begin{array}{ll}\text { Mating plan } & 134\end{array}$

Linkage estimates $\quad 137$

Strain distribution pattern $\quad 138$

$\begin{array}{ll}\text { Nomenclature } & 141\end{array}$

$\begin{array}{lll}5.7 & \text { Congenic and coisogenic inbred strains } & 141\end{array}$

Backcross system (system 2) 142

Cross-intercross system (system 3) 147

Cross-backcross-intercross system (system 4) 149

Nomenclature 151

$\begin{array}{lll}5.8 & \text { Segregating inbred strains } & 152\end{array}$

Brother-sister inbreeding with heterozygosity forced 153 by backcrosses (system 5)

Brother-sister inbreeding with heterozygosity forced 155 by intercrosses (system 6)

Brother-sister inbreeding with heterozygosity forced $\quad 157$ by crosses and intercrosses or by backcrosses and intercrosses (systems 7 and 8)

Crosses and intercrosses (system 7) 157

Backcrosses and intercrosses (system 8) 159

$\begin{array}{ll}\text { Nomenclature } & 161\end{array}$

5.9 Comparison of systems; strategies of use 161

$\begin{array}{lll}5.10 & \text { Two-locus systems } & 167\end{array}$

To propagate lethal, sterile or deleterious recessive mutations 167

To propagate handicapped, but breedable, recessive mutations 172

$\begin{array}{ll}\text { To identify recessive homozygotes early } & 173\end{array}$

To identify mice with 0,1 or 2 doses of recessive mutations $\quad 174$ 
To transfer a recessive mutation to a standard inbred background 175

To transfer a not-easily-recognised recessive mutation to a $\quad 176$ standard inbred background

5.11 Linkage estimation

5.12 Number of matings and number of mice per mating 181

$\begin{array}{lll}5.13 \text { Sources } & 184\end{array}$

Appendix 1 Mean and variance of a binomial distribution 186

Appendix 2 Estimation of a parameter by the method of maximum $\quad 188$ likelihood

A2.1 Example 1: Binomial probabilities 190

A2.2 Example 2: Multinomial distribution with one parameter 192

Appendix 3 Extensions of the method of maximum likelihood 194

A3.1 An alternative form for the amount of information 194

A3.2 Propagation of variance 196

A3.3 Amount of information per observation 197

A3.4 Use of scores 198

A3.5 Completely worked example 199

Appendix 4 Comparative efficiency of matings for detecting and 202 measuring linkage

$\begin{array}{lll}\text { Appendix } 5 \text { The Fibonacci sequence } & 210\end{array}$

$\begin{array}{lll}\text { Appendix } 6 & \text { Systems of mating } & 212\end{array}$

Appendix 7 Numbers of matings and numbers of mice per mating 217

$\begin{array}{lll}\text { A7.1 General method } & 217\end{array}$

A7.2 Number of progeny of one-locus testcrosses 218

$\begin{array}{ll}\text { A7.3 Kinds of one-locus testcrosses } & 219\end{array}$

A7.4 Number of one-locus testcrosses $\quad 220$

A7.5 Number of progeny of two-locus testcrosses 221

A7.6 Number of two-locus testcrosses with recessive mutations 223

A7.7 Number of two-locus testcrosses with a recessive mutation 224 and a dominant marker

Appendix 8 Nomenclature $\quad 226$

A8.1 Rules for gene nomenclature in mice 226

Names of gene loci 226

Symbols for gene loci $\quad 226$

Loci in series $\quad 227$

Allele symbols $\quad 227$ 
xiv

CONTENTS

Phenotype symbols $\quad 228$

Gene complexes $\quad 228$

$\begin{array}{ll}\text { Viruses } & 230\end{array}$

Antigenic variants $\quad 230$

A8.2 Guidelines for nomenclature of biochemical variants 231

$\begin{array}{ll}\text { Biochemical nomenclature } & 231\end{array}$

Symbols for structural loci $\quad 231$

Allele symbols $\quad 231$

Series of loci $\quad 232$

Phenotype symbols $\quad 232$

Identification of loci $\quad 232$

Genetic variants affecting enzyme activity of mice $\quad 232$

A8.3 Rules for nomenclature of chromosome anomalies 233

$\begin{array}{ll}\text { Symbols for chromosome anomalies } & 233\end{array}$

Nomenclature for variations in heterochromatin and chromosome 234 banding

Use of human chromosome nomenclature $\quad 234$

A8.4 Rules for nomenclature of inbred strains of mice 235

Definition of inbred strain $\quad 235$

Symbols for inbred strains $\quad 235$

Indication of inbreeding $\quad 235$

Priority in strain symbols $\quad 235$

Recombinant inbred strains $\quad 235$

$\begin{array}{ll}\text { Substrains } & 235\end{array}$

Designation of substrains $\quad 236$

Sublines $\quad 236$

Designation of sublines $\quad 236$

Coisogenic, congenic and segregating inbred strains $\quad 237$

Inbred strains of mice preserved by freezing 238

$\begin{array}{lll}\text { Appendix } 9 & \text { Record-keeping } & 240\end{array}$

A9.1 Forms 241

Cage tags $\quad 241$

Mating cards $\quad 243$

Litter cards $\quad 243$

Mating record sheet $\quad 245$

Summary cards $\quad 246$

$\begin{array}{ll}\text { Other cards and hardware } & 247\end{array}$

$\begin{array}{lll}\text { A9.2 Acts } & 249\end{array}$

Accessioning $\quad 249$

Mating $\quad 249$

$\begin{array}{ll}\text { Checking } & 249\end{array}$

Recording 250

Summarising 251

$\begin{array}{lll}\text { A9.3 Alternative system } & 251\end{array}$ 
Appendix 10 Mouseroom layout and procedures

Glossary of signs and symbols

Literature cited

Index 